\title{
Exploring Spirituality and Technology Receptivity Among a Sample of Older Blacks to Inform a Tailored Chronic Disease Self-Management mHealth Intervention
}

This article was published in the following Dove Press journal:

Patient Related Outcome Measures

\author{
Kamilah Thomas-Purcell $\mathbb{D}^{\prime}$ \\ Tochukwu Adaobi lbe ${ }^{2}$ \\ Donrie Purcell ${ }^{3}$ \\ Gwendolyn Quinn (D) ${ }^{4}$ \\ Raymond Ownby (D) ${ }^{3}$ \\ 'Department of Health Science, Dr. \\ Pallavi Patel College of Health Care \\ Sciences, Nova Southeastern University, \\ Ft. Lauderdale, FL, USA; ${ }^{2}$ Mayo Clinic, \\ College of Medicine and Science, \\ Department of Internal Medicine, \\ Jacksonville, FL, USA; ${ }^{3}$ Department of \\ Psychiatry, Dr. Kiran C. Patel College of \\ Osteopathic Medicine, Nova \\ Southeastern University, Ft. Lauderdale, \\ FL, USA; ${ }^{4}$ Department of OB-GYN, \\ Department of Population Health, New \\ York University, Langone Medical Center, \\ New York, NY, USA
}

Introduction: Having multiple chronic conditions (MCC) is the most common health condition in older US adults of which Blacks are disproportionally affected. The management of each condition presents many challenges. Blacks in the US frequently cite spirituality as facilitator to well-being. More information is needed to understand the many aspects of spirituality that older Black patients use to manage MCCs.

Methods: In the current study, focus groups were conducted with 30 black men and women with MCCs to examine how spirituality can be incorporated into a mobile health intervention designed to increase chronic disease self-management (CDSM) skills by improving health literacy. Groups discussed spiritual practices used to facilitate CDSM and their perceptions about mobile technology use.

Results: Inductive thematic analysis suggested that a chronic disease wellness plan that acknowledges the relationship between spirituality and health was preferred by most participants. Additionally, the desire for mobile health (mHealth) among this group points to an opportunity for intervention.

Discussion: Creating culturally appropriate educational messages about CDSM that incorporate spiritual practices may be a useful method for building sustainable CDSM skills. Next steps include the development of a mHealth intervention prototype based on the results and pre-testing it prior to deployment.

Keywords: spirituality, African American, qualitative, medication adherence, folk medicine

\section{Introduction}

Chronic diseases affect approximately half of American adults with 1 in 4 adults having 2 or more conditions. ${ }^{1}$ Having multiple chronic conditions (MCC) or multimorbidity is most common in older adults. ${ }^{1,2}$ This prevalence is likely due to health-care improvements, which have given rise to greater numbers of people living with MCC for longer periods of time. ${ }^{3}$ Chronic diseases are the most common causes of death in America, severely diminish health-related quality of life, and are a major contributor to health-care costs. As a result, chronic conditions have emerged as a major focus of health care.

Despite these health-care improvements, the burden of chronic conditions is not shared equally. Disparities are evident in chronic illness occurrence and health-care use according to race/ethnicity, income, and geography. ${ }^{4}$ People of color face
Correspondence: Kamilah

Thomas-Purcell

Tel +954-262-1222

Email kthomaspurcell@nova.edu 
persistent and significant disparities in health coverage that contribute to poorer health access, outcomes, and unnecessary costs. ${ }^{5}$ Specifically, there is a disproportionately higher prevalence of chronic conditions in the Black population compared to the general population, and these disparities have brought attention to the need to develop accessible and efficacious interventions to improve disease management. ${ }^{6,7}$

Self-management refers to

the ability of the individual, in conjunction with the family, community, and healthcare professionals, to manage symptoms, treatments, lifestyle changes, and psychosocial, cultural, and spiritual consequences of health conditions. $^{8}$

Self-management education (SME) refers to programs that help people who have ongoing health conditions learn strategies to help adults manage chronic conditions and live a healthier life. ${ }^{8}$ Self-management education programs teach participants information and skills related to their chronic diseases in order to increase their self-efficacy. That person must then be able to perform the necessary activities to manage the health condition. ${ }^{9}$

Spirituality has been linked to enhancing the selfmanagement of diabetes in the Black population by serving as a source of support to not only cope with their illness but to assist in following their daily self-management regimen. ${ }^{9,10}$ Relationships have also been found in studies exploring the role of spirituality in the management of chronic illnesses, such as HIV. Dalmida et al noted that Black women with HIV infection relied on sources greater than themselves to attempt to find meaning in their lives and to sustain their mental wellness. ${ }^{11}$ For many, this meant developing a closer relationship with God, which was an important aspect of their spirituality that provided inner peace and hope. ${ }^{11}$ Blacks who utilize spirituality in their chronic disease management have reported on many benefits: (a) the ability to cope and adjust, ${ }^{12-14}$ (b) feelings of inner peace and hope, ${ }^{11,15}$ improvements in physical and mental health; ${ }^{11,16}$ (c) the reduction of worries and stress; ${ }^{15}$ (d) the experience of strength and empowerment, ${ }^{13,17,18}$ (e) healing; ${ }^{11,19}$ and (d) the ability to persevere and find meaning/purpose in their illness. ${ }^{11}$ Given these findings, it may be useful to capitalize on spiritually based means of behavioral change to facilitate chronic disease management and prevent further complications among Blacks.
People of color also face persistent and significant disparities in health insurance coverage that contribute to poorer health access and outcomes, and unnecessary costs ${ }^{5}$ further eliciting a need for public health interventions to meet the health demands that are associated with this growth. ${ }^{20}$ The growing use of technology for patient health information and education can go a long way to alleviate the burden of that demand. ${ }^{21,22}$ Methods of communication such as smartphones, text messaging, social media, and web-based resources have been increasingly utilized by both patients and providers to improve patient outcomes and their experience with healthcare. ${ }^{21,22}$ These advances in technology have helped to initiate healthrelated innovations that contribute to efforts that increase access to health information, especially among the nation's underserved populations. $^{21}$ The Global Observatory for eHealth of the World Health Organization defined mobile health (mHealth) as "medical and public health practice supported by mobile devices, patient monitoring devices, personal digital assistants, and other wireless devices". ${ }^{23}$ Studies have shown promising signs that mHealth interventions within vulnerable populations help to engage patients in chronic disease self-management, health promotion behaviors and CDSM. ${ }^{24,25}$ mHealth has the potential to increase access to CDSM interventions since its applications can provide information and build skills without the limitations of time of day or physical location. ${ }^{26}$ Via this method, not only are more individuals reached at a reduced cost but there is also the ability to collect large amounts of data that can be utilized to inform more adaptive and effective programs. ${ }^{27}$

Many patients simply lack the ability to fully comprehend provider instructions for their disease management or medication prescriptions. ${ }^{28}$ This presents a challenge to clinicians who are dealing with time constraints during visits, limiting their ability to provide the appropriate health education needed. ${ }^{28}$ Growing health information technology innovations can help address these disparities by increasing the availability as well as the efficacy of patient education, which may lead to overall better patient outcomes. $^{28}$

The current study is part of a larger study whose purpose was to develop a tailored mHealth intervention that incorporates health literacy and chronic disease selfmanagement, particularly for those faced with MCC. ${ }^{29}$ This study targets several proximal outcomes including health literacy, patient activation, health-related quality of 
life, and self-reported health in patients with multiple chronic conditions. $^{29}$

Formative research for the larger study found that religion and spirituality were very important to participants and this suggested that including the topic in the mHealth intervention might be a source of strength to help patients cope with the emotional effects of MCCs and possibly influence CDSM outcomes. ${ }^{30}$ Religious and/or spiritual interventions (RSIs) typically propose the introduction of reflective discussion of religious or spiritual values and beliefs into the patient's treatment as a complementary health therapy. ${ }^{31}$ Examples of RSIs include the Faith-based Approaches in the Treatment of Hypertension (FAITH) study, a therapeutic lifestyle change intervention that included motivational interviewing ${ }^{32}$ and A New DAWN: Diabetes Awareness \& Wellness Network, a church-based diabetes self-management education intervention for African Americans. ${ }^{33}$ In an effort to understand whether and how spiritual components could be integrated into a CDSM mHealth intervention, this qualitative study examined the perceptions of the use of spirituality for CDSM and the level of technology receptivity among Black patients.

\section{Materials and Methods Design}

All study procedures followed a protocol approved by the Institutional Review Board of Nova Southeastern University. The study employed an exploratory cross-sectional study design incorporating the qualitative approach of semi-structured focus group sessions. This method is appropriate when there is a need to understand beliefs that may impact individual decision-making and other phenomena that may not be attainable using quantitative methods. Group forces or dynamics become an integral part of the procedure with participants engaged in discussion with each other rather than directing their comments solely to the moderator. ${ }^{34}$

\section{Participants}

From June 2018-September 2018 individuals were recruited as a convenience sample by engaging with multiple community-based organizations throughout Broward County, FL. Sites included a university-affiliated research center, health fairs, and local churches; all targeted the Black community. A recruitment survey screened for eligibility of the potential participants. Eligibility for participation included: (a) males or females who selfreported as Black or African American, (b) being $\geq 50$ years of age, (c) diagnosed and managing one or more chronic diseases, and (d) had no obvious indications of cognitive impairment.

Interested participants were recruited based upon their availability to attend one of the focus group sessions. Each participant selected a time that was convenient from the sessions offered. Participants were separated by gender across the groups to allow participants to feel comfortable when discussing sex-specific health issues. It has been found that men have a tendency to speak more frequently and with more authority when in groups with womensometimes called the "peacock effect". 35 This can be a source of frustration for women in the group and may negatively impact the results. Each participant was compensated for their time and transportation costs.

\section{Conceptual Framework and Instrument}

Social cognitive theory was used as the theoretical model for understanding chronic disease self-management. ${ }^{36,37}$ Social cognitive theory states that personal factors (beliefs and other cognitions) and environmental factors (physical and social) interact to influence behavior. Self-efficacy, a person's confidence in their ability to practice specific self-management behaviors, facilitates the success of self-management programs and produces positive outcomes. ${ }^{9,38}$ Self-management incorporates behavioral, personal, and environmental factors into daily performance of recommended activities. Therefore, the concept of self-efficacy is relevant for improving chronic disease self-management.

Diffusion of Innovations describes the process by which a new idea, product or positive health behavior spreads through a community or social structure. ${ }^{39}$ The model identifies several factors that influence how quickly an idea or behavior is adopted. The adoption of a new idea (or diffusion of an innovation) depends on characteristics of the innovation, communication channels, time, and the social system. ${ }^{40}$ This model highlights the barriers associated with new behaviors and helps public health program implementers consider ways to address the barriers.

The authors used a review of published literature on spirituality and mHealth to generate a semi-structured interview guide. The literature specifically reviewed for: (a) spirituality and chronic disease management; (b) types of mHealth; (c) use of mHealth in older adult populations; and (d) use of mHealth for CDSM. The interview guide was pilot tested with a group of male and female 
volunteers prior to its use with the actual study participants. Changes to the original draft were made based upon the results of pretesting feedback. See Box 1 for all of the questions included in the guide.

\section{Box I Focus Group Moderator Guide Questions}

\begin{tabular}{|l|l|}
\hline I. & What does the term chronic disease mean to you? \\
2. & What does the term chronic disease management mean to you? \\
What type of challenges do you experience with managing your \\
4. & $\begin{array}{l}\text { Are there any other factors that help you cope with your } \\
\text { chronic conditions? }\end{array}$ \\
\hline If there is no mention of spiritual or religious beliefs, then go \\
to the question 6. Skip if discussed.
\end{tabular}

\section{Procedure}

Prior to the start of each focus group all participants completed a 12-item self-administered questionnaire that inquired about demographics (eg, age, gender, self-identified race, marital status, and income), the type of chronic disease (s) diagnosis they received, religious identification, and frequency of prayer. The focus groups were led by an experienced Ph.D. level moderator. A graduate-level research assistant was present at each session to observe group processes, take notes, and document pertinent verbal and nonverbal communication. The moderator explained the purpose and format of the focus group. The consent form was read aloud, and time was provided to address concerns. Written informed consent was obtained prior to beginning each audio-recorded discussion. All participants were randomly assigned a number to use in place of their names when speaking. Participants were explicitly encouraged to express themselves openly and respectfully, without concern for whether or not other participants agreed with their opinions. Interviews lasted approximately 90 minutes. All focus group sessions were audio recorded and transcribed verbatim.

\section{Analyses}

Transcripts were imported into Dedoose qualitative analysis software for analysis (Dedoose, Los Angeles, CA, USA). An iterative process was used to analyze the focus group data. The researchers conducted a multi-step process. First, transcripts were initially reviewed by the primary author line-by-line and inductively. A code that highlighted the core meaning of the text was developed. ${ }^{41}$ For example, the phrase,

If I pick up my medication and I'm not totally sure about it, I go on there and I look for um the things that were being harmful to me, you know, even though you've got a printout, you know, yeah

was coded as "use of technology to research medications". This created the initial code book. Next, two additional coders reviewed the transcripts line-by-line and the codes were reviewed for consistency and refined. A final codebook was developed once consensus was reached. Thereafter, all three coders independently selected phrases that were relevant to each code. The team met via telephone conference to discuss the selected phrases and codes. Finally, using an iterative process, the codes were organized into themes. Descriptive statistics were gathered by entering demographic information into IBM SPSS Statistics for Windows, version 20 (IBM Corp, Armonk, NY, USA), a software platform for statistical analysis.

\section{Results}

Data reported are from five cisgender focus group sessions consisting of 3 female and 2 male sessions. The mean age of participants was 62.0 years ( $\mathrm{SD}=7.7$, range $50-78$ ). The number of women attending each focus group session was 5,7 , and 3 , while the number of males in each session were 9 and 6 for a total of 30 participants. Participants' characteristics by gender are summarized in Tables 1-3. Thirteen males reported having HIV and only 1 female. 
Table I Demographic Characteristics of Participants by Gender

\begin{tabular}{|c|c|c|c|c|}
\hline Item & Response & Male & Female & Total \\
\hline $\begin{array}{l}\text { Identify as Black } \\
\text { or African } \\
\text { American }\end{array}$ & $\begin{array}{l}\text { Yes } \\
\text { No }\end{array}$ & $\begin{array}{l}14 \\
0\end{array}$ & $\begin{array}{l}13 \\
2\end{array}$ & $\begin{array}{l}27 \\
2\end{array}$ \\
\hline $\begin{array}{l}\text { Born in the } \\
\text { United States }\end{array}$ & $\begin{array}{l}\text { Yes } \\
\text { No }\end{array}$ & $\begin{array}{l}14 \\
1\end{array}$ & $\begin{array}{l}2 \\
13\end{array}$ & $\begin{array}{l}16 \\
14\end{array}$ \\
\hline Marital status & $\begin{array}{l}\text { Single (never married) } \\
\text { Married } \\
\text { Separated } \\
\text { Divorced } \\
\text { Widowed }\end{array}$ & $\begin{array}{l}8 \\
3 \\
0 \\
3 \\
0\end{array}$ & $\begin{array}{l}3 \\
4 \\
1 \\
5 \\
2\end{array}$ & $\begin{array}{l}11 \\
7 \\
1 \\
8 \\
2\end{array}$ \\
\hline $\begin{array}{l}\text { Household } \\
\text { income before } \\
\text { taxes in the past } \\
12 \text { months }\end{array}$ & $\begin{array}{l}\text { Less than } \$ 25,000 \\
\$ 25,000 \text { to } \$ 34,999 \\
\$ 35,000 \text { to } \$ 49,999 \\
\$ 50,000 \text { to } \$ 74,999 \\
\$ 75,000 \text { to } \$ 99,999 \\
\$ 100,000 \text { to } \$ 149,999 \\
\$ 150,000 \text { or more }\end{array}$ & $\begin{array}{l}12 \\
1 \\
0 \\
0 \\
1 \\
0 \\
0\end{array}$ & $\begin{array}{l}6 \\
1 \\
2 \\
0 \\
4 \\
1 \\
0\end{array}$ & $\begin{array}{l}18 \\
2 \\
2 \\
0 \\
5 \\
1 \\
0\end{array}$ \\
\hline $\begin{array}{l}\text { Highest degree or } \\
\text { level of education } \\
\text { completed }\end{array}$ & $\begin{array}{l}\text { Less than high school } \\
\text { High school graduate } \\
\text { Some college, no degree } \\
\text { Associate degree } \\
\text { Bachelor's degree } \\
\text { Graduate or } \\
\text { professional degree } \\
\text { Ph.D. }\end{array}$ & $\begin{array}{l}6 \\
0 \\
1 \\
1 \\
4 \\
2 \\
0\end{array}$ & $\begin{array}{l}2 \\
3 \\
2 \\
2 \\
3 \\
3 \\
\\
0\end{array}$ & $\begin{array}{l}8 \\
3 \\
3 \\
3 \\
7 \\
5 \\
\\
0\end{array}$ \\
\hline
\end{tabular}

Note: *Missing responses not reported.

\section{Summary of Focus Group Results}

The four themes for this study include (a) Religion and Spirituality is a Way of Life, (b) Facilitators to CDSM, (c) Barriers to CDSM, and (d) Readiness for Technology. Within these themes were several emergent sub themes. Selected excerpts from the transcribed interviews were used to illustrate the results. Additional selected excerpts related to each theme can be found in Table 4 .

\section{Religion and Spirituality as a Way of Life}

The majority of participants identified as Christian and explained that they had frequent church attendance during childhood. Even though most reported attending some form of religious meeting at least twice per month, many stressed the importance of a spiritual life outside of formal religion. Participants explained spirituality as an appreciation for life and belief in an entity greater than oneself whether it be God, nature, or the Universe. It was seen as a holistic approach to life. In this sample, both men and women expressed that they were spiritual.
Table 2 Chronic Illness of Participants by Gender

\begin{tabular}{|c|c|c|c|c|}
\hline Item & Response & Male & Female & Total \\
\hline $\begin{array}{l}\text { Two or more chronic } \\
\text { diseases }\end{array}$ & $\begin{array}{l}\text { Yes } \\
\text { No }\end{array}$ & $\begin{array}{l}13 \\
2\end{array}$ & $\begin{array}{l}13 \\
2\end{array}$ & $\begin{array}{l}26 \\
4\end{array}$ \\
\hline $\begin{array}{l}\text { Has the following } \\
\text { conditions }\end{array}$ & $\begin{array}{l}\text { Arthritis } \\
\text { Asthma } \\
\text { Diabetes } \\
\text { Cancer } \\
\text { Heart Disease } \\
\text { High Blood } \\
\text { Pressure } \\
\text { High } \\
\text { Cholesterol } \\
\text { HIV/AIDS } \\
\text { Kidney } \\
\text { Disease } \\
\text { Multiple } \\
\text { Sclerosis } \\
\text { Obesity } \\
\text { Osteoporosis } \\
\text { Other }\end{array}$ & $\begin{array}{l}3 \\
1 \\
6 \\
0 \\
0 \\
11 \\
0 \\
13 \\
0 \\
0 \\
4 \\
0 \\
2\end{array}$ & $\begin{array}{l}7 \\
1 \\
7 \\
0 \\
1 \\
10 \\
5 \\
1 \\
1 \\
1 \\
3 \\
2 \\
4\end{array}$ & $\begin{array}{l}10 \\
2 \\
13 \\
0 \\
1 \\
21 \\
5 \\
14 \\
1 \\
1 \\
7 \\
2 \\
6\end{array}$ \\
\hline
\end{tabular}

Note: *Missing responses not reported.

Table 3 Religious and Spiritual Practices of Participants by Gender

\begin{tabular}{|c|c|c|c|c|}
\hline Item & Response & Male & Female & Total \\
\hline \multirow[t]{2}{*}{ Self-identified religion } & Christian & 12 & 15 & 27 \\
\hline & Other & 3 & 0 & 3 \\
\hline \multirow{3}{*}{$\begin{array}{l}\text { Attend formal } \\
\text { religious meetings at } \\
\text { least twice per month }\end{array}$} & Yes & 12 & 15 & 27 \\
\hline & No & 2 & 0 & 2 \\
\hline & & & & \\
\hline \multirow[t]{9}{*}{ Frequency of praying } & Not at all & 0 & 0 & 0 \\
\hline & Every few months & 0 & 0 & 0 \\
\hline & Once a month & 0 & 0 & 0 \\
\hline & A few times a & 1 & 0 & 1 \\
\hline & month & & & \\
\hline & Once a week & 1 & 1 & 2 \\
\hline & Once a day & 4 & 0 & 4 \\
\hline & More than once & 8 & 14 & 22 \\
\hline & each day & & & \\
\hline
\end{tabular}

Note: *Missing responses not reported.

\section{Spirituality is a Belief in an Entity Greater Than Oneself}

My spirituality is that I believe that there is a God, $\mathrm{He}$ is a creator and He's my master. (FG3, F)

For me spirituality is a true connection with your inner self, with your inner self in terms of our inner self 
Table 4 Additional Selected Participant Excerpts

\begin{tabular}{|c|c|c|c|}
\hline Theme & Subtheme & Excerpt & Participant \\
\hline \multirow[t]{4}{*}{$\begin{array}{l}\text { Religion and } \\
\text { Spirituality } \\
\text { as a Way of Life }\end{array}$} & $\begin{array}{l}\text { Spirituality is a belief in an } \\
\text { entity greater than } \\
\text { oneself. }\end{array}$ & $\begin{array}{l}\text { "My spirituality is that I believe that there is a God, He is a creator and He's } \\
\text { my master." }\end{array}$ & FG3, F \\
\hline & Religion is Formalized & $\begin{array}{l}\text { "it's a lifestyle that um you choose according, and I use the Bible as my guide, } \\
\text { especially the book of Proverbs. If you were to try to do everything in the } \\
\text { book of Proverbs, obey and also the commands that God has already put out } \\
\text { there, the ten. The ten commandments, there are many more, but those ten, } \\
\text { if you were to follow those ten, everything else will fall into place. }\end{array}$ & FG3, F \\
\hline & \multirow[t]{2}{*}{ Religion is Man-made } & $\begin{array}{l}\text { You know, so as for, if you start following different types of religion, I find, I'm } \\
\text { speaking only for me ... you're setting yourself up to be disappointed because } \\
\text { a lot of the times, we're not, we can't live up to expectations that a lot of } \\
\text { religions have on us. }\end{array}$ & FGI, M \\
\hline & & $\begin{array}{l}\text { So she joined this (name withheld) church and following all these different } \\
\text { rules and then decided she didn't need college anymore [multiple people } \\
\text { gasp]. Because they told her as a female, she didn't need to have any college } \\
\text { education because she is supposed to be getting married, having children, this } \\
\text { that and the other. }\end{array}$ & $\mathrm{FG} 2, \mathrm{~F}$ \\
\hline \multirow[t]{6}{*}{$\begin{array}{l}\text { Facilitators to Chronic Disease } \\
\text { Self-management }\end{array}$} & \multirow[t]{3}{*}{ The power of prayer } & $\begin{array}{l}\text { "And I have this thing about, people may get me angry, disappointments may } \\
\text { come, whether it's emotionally, financially, whatever. But just the fact that I } \\
\text { know God gave me a new day, [unclear], it calms me down. And I always say } \\
\text { to myself when the stress that I get, "This too shall pass." }\end{array}$ & $\mathrm{FG} 2, \mathrm{~F}$ \\
\hline & & $\begin{array}{l}\text { And I'm in there reading the thing, she [the physician] come back, I'm in tears. } \\
\text { I'm like, 'oh my goodness.' She said you're reading it, huh. She said, 'You want } \\
\text { to pray?' And I'm like, 'For real? Yes!' I mean I really broke down. }\end{array}$ & $\mathrm{FG} 5, \mathrm{~F}$ \\
\hline & & $\begin{array}{l}\text { She [the physician] pray with me and she pray when l'm leaving, before she } \\
\text { prescribe anything, yeah. And that was, that really touched me, you know. } \\
\text { And I just, sometimes I would go to her, just pay the money and go because I } \\
\text { wanted to meet with her, you know, and that that says to me, a lot. She } \\
\text { would never be in a rush to get you out, you know, like most of the doctors } \\
\text { in-and-out, you know. She listen to you and she pray with you }\end{array}$ & FG3, F \\
\hline & Use of Natural remedies & $\begin{array}{l}\text { I get the karela bush, the cerasee bush and I boil it. And I make juice out of it, } \\
\text { like mauby. I add my anise essence, and so on, and it takes just like mauby... } \\
\text { They said it can keep your blood sugar low, you know, from getting too high. } \\
\text { Keep your blood sugar level, down. I don't know but since they say it's good, } \\
\text { it's good for your blood sugar and high blood pressure and all that. When I } \\
\text { see it around my yard, I boil some. }\end{array}$ & FG2, F \\
\hline & \multirow[t]{2}{*}{ Stress Management } & $\begin{array}{l}\text { I agree what he said about stress because stress is a big part of taking care of } \\
\text { yourself. I I've learned not to let things bother me because when I get } \\
\text { stressed out my body starts to break down. }\end{array}$ & FGI,M \\
\hline & & $\begin{array}{l}\text { Thankfully stress is just how you handle it. How you handle it, you know. Do } \\
\text { you handle it in a positive manner, or do you handle it in a negative manner? } \\
\text { And you know, positive manner means that you work through it. }\end{array}$ & FGI, M \\
\hline
\end{tabular}

(Continued) 
Table 4 (Continued).

\begin{tabular}{|c|c|c|c|}
\hline Theme & Subtheme & Excerpt & Participant \\
\hline \multirow[t]{2}{*}{$\begin{array}{l}\text { Barriers to Chronic Disease } \\
\text { Self-Management }\end{array}$} & $\begin{array}{l}\text { The Challenge of } \\
\text { Medication Adherence }\end{array}$ & $\begin{array}{l}\text { "Uric acid and I have too much uric acid in my body. So I did not take it } \\
\text { seriously but when I um stopped taking the tablet that she gave me, when I } \\
\text { went back to her, she told me, the doctor told me, "You got to take the } \\
\text { medicine. It's not going to heal you, but it will maintain ..." }\end{array}$ & FG3, $F$ \\
\hline & $\begin{array}{l}\text { The Lack of Diet and } \\
\text { Exercise }\end{array}$ & $\begin{array}{l}\text { You know, with me, with my chronic illnesses and so, you know, whenever I } \\
\text { go to the doctor, my bloodwork is, you know, pretty good, but I know I need } \\
\text { to lose some weight. I know I need to get it off, but that's the hardest thing, I } \\
\text { love to eat. }\end{array}$ & FG4, M \\
\hline \multirow[t]{7}{*}{$\begin{array}{l}\text { Readiness for Technology for } \\
\text { Disease and Medication } \\
\text { Education }\end{array}$} & \multirow[t]{3}{*}{ Information seeking } & $\begin{array}{l}\text { Many many times I go on the computer and look up, I like to look up things } \\
\text { like, illnesses, all the contraindications. And and what you can do to help } \\
\text { reduce in terms of, eliminate symptoms or whatever. }\end{array}$ & FG 2, F \\
\hline & & $\begin{array}{l}\text { It's helpful to me cause I wanted to know why I have a pain in my back. And } \\
\text { this morning I went on there and they were telling me I can go to a } \\
\text { chiropractor and he, there's a new something that they can use to help with } \\
\text { the pain. }\end{array}$ & FG 2, F \\
\hline & & "Researching medications, side effects." & FGI, M \\
\hline & mHealth & $\begin{array}{l}\text { if I go to one doctor or one hospital, and they can go and just pull up your } \\
\text { thing right away, I think they will be better able to serve you if they are able } \\
\text { to do that. Because many times you go to a doctor and they say they need } \\
\text { some record }\end{array}$ & FG 3, M \\
\hline & \multirow{2}{*}{$\begin{array}{l}\text { Barriers to technology } \\
\text { use }\end{array}$} & "I have my children, that [when] I don't understand, I can call." & FG 2, F \\
\hline & & $\begin{array}{l}\text { "When it comes to your health, I do not think that should be put no, into } \\
\text { computers or different things, cause it, it could be put in the wrong hands. }\end{array}$ & FGI, M \\
\hline & Recommendations & $\begin{array}{l}\text { Just leave some Daily Word stuff there that they can pick up and read while } \\
\text { sitting in the waiting room. Some people may get more spiritually inspired, } \\
\text { you know? }\end{array}$ & FG2, F \\
\hline
\end{tabular}

Abbreviations: FG, focus group; F, female; M, male.

definitely emanates to the outside world. And that has all the influences. Spirituality also encompasses the whole aspect of the universe for me in terms of creation and so forth. It could be for, give an analogy just the fact of seeing a beautiful tree, or looking up at the sky and so forth. And truly understanding just how minute that you absolutely are and what a gift universe. Spirituality to me encompasses the total aspect of my being and it basically, all the energy that you take in and so forth. (FG4, M)

\section{Religion is Communal}

Whereas spirituality was explained as something within an individual, religion was explained as a way to share your spirituality with others.

Religious meaning I'm interacting with my fellow human beings in the worship of that God. (FG1, M)
You need fellowship, you need at least, like the Bible, bring one or two are gathered together, He'd be in the mix. (FG2, F)

\section{Religion is Formalized}

Religion was considered to be a formalized version of spirituality. Many described it as following a particular guideline such as those found in the Bible.

Religion is just the name given to whatever spiritual organization. To me, that's what religion is. And how um, the way you act through that organization. Some may have their do's and their don'ts. (FG1, M)

\section{Facilitators to Chronic Disease Self-Management}

It was clear from the responses that both men and women had a firm understanding that chronic diseases were illnesses that are ongoing and could be treated with self- 
management, but not always cured. As one female participant stated,

Chronic disease is a disease you have been living with it for, for years. And the medications that you take just kind of maintain the disease. It doesn't cure it. (FG 2, F)

There were several subthemes related to facilitators for controlling their chronic diseases. These were the power of prayer, natural remedies, and the importance of managing stress. Participants' cultural contexts were evident in the responses.

\section{The Power of Prayer}

Multiple participants discussed the reliance on prayer for both physical and emotional issues. Prayer is used to heal pain and disease, to support physician competence and to reduce the side effects of medication.

Um the spiritual part of it is that um as Christian, as a Christian, I pray and I trust that God hears my prayer. (FG3, F)

Um from experience I can speak, that there was one time in my life when I had arthritis in my back and I prayed about it and others prayed with me. And I was relieved of that. I would say that I had a miracle then. (FG3, F)

Participants felt that it was likely against some professional code for caregivers to pray with patients. However, they expressed the desire for prayer and spirituality in their wellness plans.

And I'm in there reading the thing, she [the doctor] come back, I'm in tears. I'm like, "oh my goodness." She said you're reading it, huh. She said, "You want to pray?" And I'm like, "For real? Yes!" I mean I really broke down. (FG5, F)

\section{Use of Natural Remedies}

The female participants mentioned the use of herbal remedies to manage their chronic disease. For most, these remedies were passed down to them by family members or by word of mouth by talking to other women.

And um and like I say, those those um supplements that I do take, I just feel like, because of the research you know that, they do something, you know, so I take those along with my cholesterol medication. (FG 5, F)
Sometimes we have to revert to the herbs because we know that the natural herbs don't have those side effects, you know. (FG3, F)

Some expressed concerns about using herbal remedies as exemplified below:

It's good we do herbs, I do it but where do we draw the line? How do we know when we, we drop our blood pressure too low because we are doing the herbs and the medication at the same time? (FG3, F)

\section{Stress Management}

Participants recognized the role of stress in chronic disease self-management.

... you know, try to try to manage your stress level you know, because stress often can bring up a lot of ... I mean, it increases a lot of chronic illness into uh uh a stage where you know, where it can be real detrimental to you." (FG1, M)

\section{Barriers to Chronic Disease Self-Management The Challenge of Medication Adherence}

Participants admitted that they have issues with taking their medications as prescribed. Examples given included the side effects of the medications, lack of awareness of the importance, and the desire to make create their own regimen.

I don't have a set routine. Whenever I remember, I take it. That's how I take my medication. ... they say I'm a diabetic, I test my sugar on a regular basis, see that it's within margin. If I see it's within the margin, I take no tablet, for days. (FG 3, F)

\section{The Lack of Diet and Exercise}

The lack of a balanced diet and regular exercise regimen was cited as a major contributor to chronic disease complications.

I love to eat. I love to eat different foods and that doesn't help with any type of chronic illness, it doesn't help with health, period. But um, I'm learning to manage my cravings. (FG5, F)

I challenge uh, I have a lot of things challenge we're facing uh, pre-diabetic, not diabetic, uh A1C level's 6.1. And I have to watch the food I eat, so that's a challenge. We know that rice is no good for us, bread, so we have to eat that in moderate. (FG3, F) 


\section{Readiness for Technology for Disease and Medication Education \\ Information Seeking}

The majority of participants stated that they use computers regularly to get information about their illnesses, research their medications and side effects, and to get recommendations for symptom reduction.

I use computers, technology, and I do um time to time, with something I'm not understanding medically, I do use it, you know, go there and check. And I may go over to google or someplace. (FG 2, F)

\section{mHealth}

Participants were very interested in mHealth for virtual appointments, keeping track of medical records, and for health education.

Also uh doctors have the health portal ... I like that. Make appointments and cancel.” (FG 2, F)

I'll be glad when we can get to the point where I don't have to leave my house and I can still have my doctor's appointment; I can talk to my doctor from home and have my doctor visit right in my house. And he can call my prescription right into my pharmacy and I ain't gotta leave my house. (FG1, M)

\section{Barriers to Technology Use}

A few participants admitted that they would like to use technology but a lack of knowledge in how to use computers and cell phone applications beyond simple internet searches and texting was a major barrier.

Oh yeah, I mean, pain in the butt because everything now is www. So you almost feel like, at least that's what I feel like, you're illiterate if you're not, if you don't have any computer skills. So basically I had no other choice, so I've been involved with a computer lab where I live. (FG 4, M)

Others were skeptical about the ability to maintain privacy and the loss of face-to-face interactions.

The only thing I, I'm afraid of with that is your record getting into the wrong hands ... And that's why I said aspects of it because um the problem with information when you gather it, eventually it's used and it can be used against you. (FG 3, M)

I think uh the negative side is people are getting to the point where they're losing that personal touch. (FG 4, F)

\section{Recommendations}

Those interested suggested ways to incorporate spirituality into an mHealth education application or into health care in general:

I think testimonials would be great uh, we could learn from somebody testimony, what they been through, their struggle. And I think um maybe um like uh something like this, a focus group, see uh, which I don't fear you no more, I'm open with myself. (FG4, M)

Inspirational passages. I enjoy reading cause it builds up my faith. And um it just, it inspires me to be strong, and to know that I'm going to get through this. $(\mathrm{FG} 2, \mathrm{~F})$

Additional participant excerpts can be found in Table 4 .

\section{Discussion}

We conducted an exploratory study to examine the role of spirituality in chronic disease self-management and to determine the appropriateness of including spirituality in a tailored mHealth intervention designed to increase chronic disease self-management (CDSM) skills by improving health literacy. We were also interested in mHealth receptivity among an older sample of Blacks. The first major finding was the existence of a strong desire to include spirituality into a wellness plan for CDSM. Our second major finding was that there is a desire for the incorporation of technology for the management of single or multiple chronic diseases among older Blacks.

To date, research has demonstrated that religious involvement or the existence of a spiritual life is associated with less cardiovascular disease, lower blood pressure and less hypertension, less depression, more exercise, greater use of preventive services, and overall good health. Researchers continue to search for religious and/or spiritual interventions (RSI) strategies to stimulate and develop the spiritual dimension of the patient in an effort to promote clinical improvement.

This study suggests that older adults with self-reported chronic disease include spirituality as a primary tool for chronic disease management. Participants were clear that they would like to include prayer and spirituality as a part of their wellness plans. They expressed spirituality as a way of life and important for coping with the stress of chronic disease.

Though this older population used traditional medicine, prayer was regarded as a panacea for coping with all of life's physical and emotional challenges including 
management their chronic disease. This is similar to a previous study of 157 hospitalized adults with moderate to high levels of pain, prayer was second only to pain medications ( $76 \%$ vs $82 \%$ ) as the most common selfreported means of controlling pain. ${ }^{42}$ Prayer is an important aspect of spirituality that should be included in a RSI.

In addition to the positive attributes of spirituality, participants noted negative aspects of religion that could be associated negative well-being. Patients stressed that religion is man-made and had concerns about dishonesty and unrealistic expectation. Literature in this area states that religiously involved persons may have unrealistically high expectations for themselves in terms of morality and personal behavior leading to isolation, stress, and anxiety. ${ }^{43}$ Additionally, unhealthy belief systems (eg, religious fanaticism and cults) can adversely affect health. ${ }^{43}$ For those participants with a negative perception of organized religion, a RSI focused on spiritually may serve as a supplement or alternative to traditional church services. Researchers should be aware of negative perceptions of religion when developing RSIs.

The use of traditional herbs, especially among women, was found to be a facilitator to CDSM. Initially thought of as primitive medicine, today traditional, folk, and complementary and alternative medicine (CAM) are recognized as providing a positive value to health. ${ }^{44} \mathrm{~A}$ study by Crammer et al examined associations between CAM use and spiritual well-being among 4000 cancer survivors in the United States. ${ }^{45}$ They found that subscales of Meaning and Faith, as measured by the Functional Assessment of Chronic Illness Therapy-Spiritual Well-being (FACIT-SP12) questionnaire, were positively associated with CAM use. Male and female participants in the current study expressed that spirituality included a connection to nature. Therefore, the use of herbal medicine can be considered an expression of spirituality in this context. Given the wide use of folk medicine among Blacks, public health approaches are needed to address the many challenges including safety, efficacy, quality, dosage, and rational use.

The primary barrier to CDSM experienced by the participants in the current study was medication adherence and included: forgetting to take pills, not taking medication because of side effects, or taking medication (or not) when they felt like it. Taking medications (or not) might mean "taking control" over one's illness ${ }^{46}$ or it might mean "managing symptoms". 47 Barriers to medication adherence among African-Americans include knowledge, beliefs, attitudes, self-efficacy, depression, negative health-care experiences, and poor doctor-patient communication. ${ }^{48}$ Additionally, cultural and language differences, and socioeconomic status interact with and contribute to low health literacy, defined as the inability to understand or act on medical/therapeutic instructions. 49

Literature indicates that older adults often become just as engaged and active in online activities as younger adults. $^{50}$ The majority of participants in the study expressed that they used the internet to obtain information about their disease. Most were comfortable with the internet and sending and receiving text messages. They appreciated text messages about appointments and prescription reminders; however, fewer participants used health applications to manage their health records and appointments. Many stated that they would like to do more with applications and technology but admitted that they were not as comfortable with technology as they would like to be. This is consistent with a 2013 Pew Research study that found that $18 \%$ of older adults said would feel comfortable learning to use a new technology device such as a smartphone or tablet on their own, while $77 \%$ indicated they would need someone to help walk them through the process. $^{51}$

A negative perception of mHealth expressed by participants was mistrust of its ability to maintain privacy which is consistent with previous research. ${ }^{52}$ The Diffusion of Innovations research model states, at the outset, fewer people are trusting of the innovation and the percentage of adoption is low. ${ }^{40}$ In this situation, effective communication on the latest updates in online privacy and confidentiality may assuage some of these concerns and help an innovation become more popular.

Overall, participants were open to using technology as part of their chronic disease management and they were interested in incorporating spirituality into their health care. The adoption and use of technology among older adults has grown significantly in recent years with the aging of Baby Boomers. ${ }^{53}$ Participants offered suggestions for how to incorporate spirituality into a mHealth intervention, which included the use of testimonials, bible passages, and inspirational messages. They were also open to receiving this information in waiting rooms providing additional evidence that spirituality in the clinical setting is welcomed. Few studies have incorporated cultural factors into their health-related technological interventions. A systematic review of eHealth interventions to improve health literacy found that only two interventions were linguistically and culturally adapted, and two others 
recruited participants on the basis of racial characteristics (African Americans). ${ }^{54}$ Little is known about the intersectionality between chronic disease self-management and technology use amongst African Americans. In one review of four studies evaluating the use of technology (eg, telephone-based, e-Health, text messaging) for self-management of heart failure in African Americans, the researchers concluded that the participants largely reported positive usability and acceptability of the interventions, viewed the technologies as a means of providing support, and experienced improved health outcomes related to selfmanagement, re-hospitalizations, costs, and quality of life. $^{55}$

mHealth interventions can potentially influence healthrelated behavior (and, in turn, health outcomes) via effecting changes in mediators of behavior change such as knowledge, attitudes, community peer norms, beliefs and self-efficacy. Given the interest and positive receptivity of mHealth, training sessions and support for older adults learning technology could have a major impact on increasing the number of older adults using these technologies to manage their chronic diseases. It has been documented that older adults have an interest in learning about computers and the internet when given the opportunity and training. ${ }^{56}$ Training could take place in a variety of settings including churches, community centers, in the health-care setting as part of an appointment, or even online.

This study is unique in that it explored the perspectives of the incorporation of a spiritual component for the development of an mHealth RSI. This preliminary research is important for the development of a culturally relevant interventions. Despite the beneficial information gleaned from this study, there are several limitations that must be noted.

First participants were self-selected to participate in the study. We used convenience and snowball sampling to comprise our focus groups. This sampling method limits the generalizability of the study. Those who participated may have been more likely to support incorporating spirituality into chronic a disease management program. Demographic information collected prior to the start of the focus group indicated that $93 \%$ of participants attended formal religious meetings at least twice per month and $97 \%$ indicated that they pray one per week to more than twice per day. Future studies should include participants with lower scores on religious meeting attendance in order to get a more rounded perspective.

Previous research has shown that spirituality is deeply embedded in the rich cultural heritage of Blacks. ${ }^{57,58} \mathrm{It}$ should be noted that the aim of this study was to represent a range of perceptions to better understand the topic, rather than collect a demographically representative sample. Future research should examine additional demographic groups to determine if the results are similar.

\section{Conclusion}

The older adults in this study reported important information about the use of spirituality for managing chronic disease and provided insight on the potential use of mHealth for CDSM. This study was initiated to guide the development of a tailored mHealth intervention that focuses on spirituality to improve health literacy and chronic disease self-management, particularly for those faced with multiple chronic conditions. We will integrate the results expressed by our participants to incorporate spirituality into a mHealth educational intervention designed to increase CDSM skills by improving health literacy. Next steps include developing a prototype of the intervention and pre-testing it with a group of older Blacks prior to deployment. Further research is needed to determine the particular barriers that may prohibit older adults from correctly using mHealth applications and determining design preferences. This study contributes to the evidence base for the practicality of incorporating spirituality in mHealth interventions and the receptivity of technology and mHealth among a group of older Blacks. The results provide a starting point for the development of a health literacy mHealth intervention for Blacks that incorporates spirituality.

\section{Funding}

Research reported in this publication was supported by the National Institute on Minority Health and Health Disparities of the National Institutes of Health under Award Number R01MD010368 -03S1. The content is solely the responsibility of the authors and does not necessarily represent the official views of the National Institutes of Health.

\section{Disclosure}

Research reported in this manuscript was supported by Dr. Thomas-Purcell's grant from the National Institute on Minority Health and Health Disparities of the National Institutes of Health under Award Number R01MD010368 -03S1. Dr. Raymond Ownby reports grants from the US National Institutes of Health, during the conduct of the study; in addition, Dr Raymond Ownby has a patent pending US2019/ 013319, Assessment of human 
comprehension by an automated agent. The authors report no other conflicts of interest in this work.

\section{References}

1. Ward BW, Schiller JS, Goodman RA. Multiple chronic conditions among US adults: A 2012 update. Prev Chronic Dis. 2014;11:E62. doi:10.5888/pcd11.130389

2. Institute of Medicine. Living Well with Chronic Illness: A Call for Public Health Action. Washington, DC: IOM (Institute of Medicine).

3. Grady PA, Gough LL. Self-management: A comprehensive approach to management of chronic conditions. Am J Public Health. 2014;104 (8):e2531. doi:10.2105/AJPH.2014.302041

4. Anderson GF. Medicare and chronic conditions. $N$ Engl $J$ Med. 2005;353(3):305-309. doi:10.1056/NEJMsb044133

5. Kaiser Family Foundation. Health coverage by race and ethnicity: the potential impact of the affordable care act. kaiser family foundation; Published 2013. Updated 2020. 2020. Available from: https://www. kff.org/disparities-policy/issue-brief/health-coverage-by-race-and-eth nicity-the-potential-impact-of-the-affordable-care-act/. Accessed February 19, 20.

6. Collins-McNeil J, Edwards CL, Batch BC, Benbow D, McDougald CS, Sharpe D. A culturally targeted self-management program for African Americans with type 2 diabetes mellitus. Can J Nurs Res. 2012;44(4):126-141.

7. Phillips KL, Rogers CR, Aiken-Morgan AT. Perceptions of chronic disease among older African Americans: A qualitative analysis. $J$ Health Dispar Res Pract. 2017;10(4):52-60.

8. Richard A, Shea K. Delineation of self-care and associated concepts. J Nurs Scholarsh. 2011;43(3):255-264.

9. Clark NM, Becker MH, Janz NK, Lorig K, Rakowski W, Anderson L. Self-management of chronic disease by older adults: A review and questions for research. J Aging Health. 1991;3(1):3-27. doi:10.1177/ 089826439100300101

10. Richard AA, Shea K. Delineation of self-care and associated concepts. J Nurs Scholarsh. 2011;43(3):255-264.

11. Dalmida SG, Holstad MM, DiIorio C, Laderman G. The meaning and use of spirituality among African American women living with HIV/ AIDS. West $J$ Nurs Res. 2012;34(6):736-765. doi:10.1177/ 0193945912443740

12. Harvey IS, Cook L. Exploring the role of spirituality in self-management practices among older African-American and non-Hispanic White women with chronic conditions. Chronic Illn. 2010;6(2):111124. doi: $10.1177 / 1742395309350228$

13. Harvey IS, Silverman M. The role of spirituality in the self-management of chronic illness among older African and Whites. $J$ Cross Cult Gerontol. 2007;22(2):205-220. doi:10.1007/s10823-007-9038-2

14. Polzer RL, Miles MS. Spirituality in African Americans with diabetes: self-management through a relationship with God. Qual Health Res. 2007;17(2):176-188. doi:10.1177/1049732306297750

15. Polzer Casarez RL, Miles MS. Spirituality: A cultural strength for African American mothers with HIV. Clin Nurs Res. 2008;17(2):118132. doi: $10.1177 / 1054773808316735$

16. Boyd-Franklin N. Incorporating spirituality and religion into the treatment of African American clients. Couns Psychol. 2010;38 (7):976-1000. doi:10.1177/0011000010374881

17. Becker G, Gates RJ, Newsom E. Self-care among chronically ill African Americans: culture, health disparities, and health insurance status. Am J Public Health. 2004;94(12):2066-2073. doi:10.2105/ AJPH.94.12.2066

18. Samuel-Hodge CD, Headen SW, Skelly AH, et al. Influences on day-today self-management of type 2 diabetes among African-American women: spirituality, the multi-caregiver role, and other social context factors. Diab Care. 2000;23(7):928-933. doi:10.2337/diacare.23.7.928
19. Potts RG. Spirituality and the experience of cancer in an AfricanAmerican community: implications for psychosocial oncology. $J$ Psychosoc Oncol. 1996;14(1):1-19. doi:10.1300/J077v14n01_01

20. Orgera K, Artiga S Disparities in health and health care: five key questions and answers. henry $\mathrm{j}$ kaiser family foundation. Available from: http://files.kff.org/attachment/Issue-Brief-Disparities-in-Healthand-Health-Care-Five-Key-Questions-and-Answers. Published 2018.

21. Barclay G, Sabina A, Graham G. Population health and technology: placing people first. Am J Public Health. 2014;104:2246-2247. doi:10.2105/AJPH.2014.302334

22. Randolph S, Cary M, Gonzalez-Guarda R. The use of technology for health information for African American men. $J$ Healthc Commun. 2017;2:2. doi:10.4172/2472-1654.100058

23. WHO Global Observatory for eHealth. mHealth: New Horizons for Health Through Mobile Technologies: Second Global Survey on eHealth. Geneva, Switzerland; 2011.

24. Krishna S, Boren SA. Diabetes self-management care via cell phone: A systematic review. J Diabetes Sci Technol. 2008;2(3):509-517. doi:10.1177/193229680800200324

25. Neville R, Greene A, McLeod J, Tracey A, Surie J. Mobile phone text messaging can help young people manage asthma. $\mathrm{Br}$ Med $\mathrm{J}$. 2002;325(7364):600. doi:10.1136/bmj.325.7364.600/a

26. Jerant A, Sohler N, Fiscella K, Franks B, Franks P. Tailored interactive multimedia computer programs to reduce health disparities: opportunities and challenges. Patient Educ Couns. 2011;85(2):323330. doi:10.1016/j.pec.2010.11.012

27. Oldenburg B, Taylor CB, O'Neil A, Cocker F, Cameron LD. Using new technologies to improve the prevention and management of chronic conditions in populations. Annu Rev Public Health. 2015;36 (1):483-505. doi:10.1146/annurev-publhealth-031914-122848

28. Gibbons MC. Use of health information technology among racial and ethnic underserved communities. Perspect Health Inf Manag. 2011;8:1f.

29. Ownby RL, Acevedo A, Waldrop-Valverde D, et al. A mobile app for chronic disease self-management: protocol for a randomized controlled trial. JIMR Res Protoc. 2017;6(4):e53. doi:10.2196/ resprot.7272

30. Ownby RL, Acevedo A, Waldrop-Valverde D, et al. Development and initial validation of a computer-administered health literacy assessment in Spanish and English: FLIGHT/VIDAS. Patient Relat Outcome Meas. 2013;4:1-15.

31. Gonçalves JP, Lucchetti G, Menezes PR, Vallada H. Complementary religious and spiritual interventions in physical health and quality of life: A systematic review of randomized controlled clinical trials. PLoS ONE. 2017;12(10):e0186539. doi:10.1371/journal.pone.018 6539

32. Schoenathaler AM, Lancaster KJ, Chaplin W, Butler M, Forsyth J, Ogedegbe G. Cluster randomized clinical trial of FAITH (FaithBased Approaches in the Treatment of Hypertension) in blacks. Circulation. 2018;11:10.

33. Samuel-Hodge CD, Keyserling TC, France R, et al. A church-based diabetes self-management education program for African Americans with type 2 diabetes. Prev Chronic Dis. 2006;3(3):A:93.

34. Morgan DL. Focus Groups as Qualitative Research. Newbury Park: CA: Sage; 1988.

35. Krueger R, Casey MA. Focus Groups: A Practical Guide for Applied Research. 5th Edition ed. Thousand Oaks, CA: Sage Publications, Inc; 2015.

36. Bandura A. Self-efficacy mechanism in human agency. Am Psychol. 1982;37(2):122-147. doi:10.1037/0003-066X.37.2.122

37. Bandura A. Social Foundations of Thought and Action: A Social Cognitive Theory. Englewood Cliffs, NJ: Prentice-Hall, Inc; 1986.

38. Lorig KR, Holman H. Self-management education: history, definition, outcomes, and mechanisms. Ann Behav Med. 2003;26(1):1-7. doi:10.1207/S15324796ABM2601_01 
39. Rogers EM. Diffusion of Innovations. 5th ed. New York, NY: Free Press; 2003.

40. Rogers EM. Diffusion of Innovations. In: An Integrated Approach to Communication Theory and Research. Fifth edition. Salwen M, Stacks D, editors. Mahwah, NJ: LEA; 2003:409-419.

41. Graneheim UH, Lundman B. Qualitative content analysis in nursing research: concepts, procedures and measures to achieve trustworthiness. Nurse Educ Today. 2004;24(2):105-112. doi:10.1016/j.nedt. 2003.10.001

42. McNeill JASG, Starck PL, Thompson CJ. Assessing clinical outcomes: patient satisfaction with pain management. J Pain Symptom Manage. 1998;16:29-40. doi:10.1016/S0885-3924(98)00034-7

43. Koenig HGMM, Larson DB. Handbook of Religion and Health. New York, NY: Oxford University Press; 2001.

44. duToit BM. Ethnomedical (Folk) Healing in the Caribbean. In: Healing Cultures. Olmos MF, GL P, editors. New York: Palgrave Macmillan; 2001.

45. Crammer C, Kaw C, Gansler T, Stein K. Cancer survivors' spiritual well-being and use of complementary methods: a report from the American cancer society's studies of cancer survivors. $J$ Relig Health. 2011;50(1):92-107. doi:10.1007/s10943-010-9327-x

46. Conrad P. The meaning of medications: another look at compliance. Soc Sci Med. 1985;20(1):29-37. doi:10.1016/0277-9536(85)90308-9

47. Hunt LM, Jordan B, Irwin S, Browner CH. Compliance and the patient's perspective: controlling symptoms in everyday life. Cult Med Psychiatry. 1989;13:315-334. doi:10.1007/BF00054341

48. Elder K, Ramamonjiarivelo Z, Wiltshire J, et al. Trust, medication adherence, and hypertension control in southern African American men. Am J Public Health. 2012;102(12):2242-2245. doi:10.2105/ AJPH.2012.300777

49. Shaw SJ, Huebner C, Armin J, Orzech K, Vivian J. The role of culture in health literacy and chronic disease screening and management. J Immigrant Minority Health. 2008;11(6):531. doi:10.1007/ s10903-008-9149-z
50. Cresci MKYH. Morrell RW The digital divide and urban older adults. Comput Inform Nurs. 2010;28:88-94. doi:10.1097/NCN.0b013e31 $81 \mathrm{~cd} 8184$

51. Pew Research Center. Older Adults and Technology Use: Adoption is Increasing, but Many Seniors Remain Isolated from Digital Life; 2014.

52. Parker S, Jessel S, Richardson JE, Reid MC. Older adults are mobile too! Identifying the barriers and facilitators to older adults' use of mHealth for pain management. BMC Geriatr. 2013;13(43):1-8. doi:10.1186/1471-2318-13-43

53. Anderson MPA. Tech adoption climbs among older adults; 2017. Available from: https://www.pewresearch.org/internet/2017/05/17/ tech-adoption-climbs-among-older-adults/. Published May 1717. Accessed October 1, 20.

54. Jacobs RJ, Lou JQ, Ownby RL, Caballero J. A systematic review of eHealth interventions to improve health literacy. Health Informatics J. 2016;22(2):81-98. doi:10.1177/1460458214534092

55. Hughes HA, Granger BB. Racial disparities and the use of technology for self-management in blacks with heart failure: a literature review. Curr Heart Fail Rep. 2014;11(3):281-289. doi:10.1007/ s11897-014-0213-9

56. Adler R Older Americans, broadband and the future of the net; 2006. Available from: http://www.seniornet.org/research/ SeniorNetNNPaper060606.pdf. Accessed October 1, 20.

57. Mbiti JS. African Religions and Philosophy. 2nd ed. Oxford, UK: Heinemann; 1989.

58. Stewart CF III. Oul Survivours: An African American Spirituality. Louisville, KY: Westminster John Knox; 1997.

\section{Publish your work in this journal}

Patient Related Outcome Measures is an international, peer-reviewed, open access journal focusing on treatment outcomes specifically relevant to patients. All aspects of patient care are addressed within the journal and practitioners from all disciplines are invited to submit their work as well as healthcare researchers and patient support groups.
The manuscript management system is completely online and includes a very quick and fair peer-review system. Visit http://www. dovepress.com/testimonials.php to read real quotes from published authors. 